http://dx.doi.org/10.4314/jae.v16i2.10

\title{
Contribution of Livestock Production to Climate Change and Mitigation Options: A Review
}

\author{
Jane M. Chah and E.M. Igbokwe \\ Department of Agricultural Extension University of Nigeria Nsukka
}

\begin{abstract}
An attempt is made to understand the role livestock production plays in climate change and to identify mitigation strategies to cap or reduce greenhouse (GHG) emissions. Scientific literature on farm animal production and documented GHG emission, as well as mitigation strategies were synthesized and used for the study. Results show that animal agriculture sector is responsible for approximately $18 \%$, or nearly one-fifth of human induced greenhouse gas (GHG) emissions. In nearly every step of meat, egg, and milk production, climate changing gases are released into the atmosphere potentially disrupting weather, temperature and ecosystem health. As the number of farm animals increases, so do their GHG emissions. Cattle rearing alone generate more global warming GHGs, as measured in carbon dioxide $\left(\mathrm{CO}_{2}\right)$ equivalent, than transportation. Immediate and far reaching changes in current animal agriculture practices and consumption patterns are both critical if GHGs from the farm animal sector are to be mitigated. However, the approaches that best reduce emissions depend on local conditions and therefore vary from region to region. In Nigeria emission of GHGs is generally low based on low per capita energy and other resource consumption. However, it is expected that there will be future rise as a result of increased numbers of livestock and high population growth rate with corresponding increase in per capita energy and other resource consumption. The assessment of options to reduce future GHG emissions is considered an important contribution to sustainable development of Nigeria. Efficacious plants peculiar to the Nigerian environment and conditions should be planted and maintained around cities. Also government should support waste management in all the states in Nigeria to have a sequel structure to safe disposal of organic matter from cattle.
\end{abstract}




\section{Introduction}

The livestock sector accounts for $40 \%$ of the world's agriculture gross domestic product (GDP) (FAO, 2006). It employs 1-3 billion people, and creates livelihood for one billion of the world's population living in poverty (FAO, 2006). Ample cattle are found in Nigeria for both dairy and beef purposes. Livestock population in Nigeria has been estimated to consist of 1.6 million cattle, 13.5 million sheep, 26 million goats, approximately 2.2million pigs and 150 million poultry (Stephen, 2010). Studies have shown that livestock contributes immensely to global warming which leads to climate change.

One of the environmental threats our planet faces today is the potential for longterm changes in the earth's climate and temperature patterns known as global climate change It is estimated that as a result of global climate change, the earth's average temperature could increase as much as six and one half degree Fahrenheit by year 2100 (Knipmeyer, Garton, and Birkenholz, 1998). The five warmest years since the 1890s were 1998, 2002, 2003, 2004 and 2005 (NASA (National Aeronautics and space Administration, 2006). Average global temperatures have risen considerably and the Intergovernmental Panel on Climate Change (IPCC, 2007) predicts increases in global average surface temperature to be $1.8-4^{\circ} \mathrm{C}$ by 2100 . These temperature rises are much greater than those seen during the last century, when average temperature rose only $0.06^{\circ} \mathrm{C}\left(0.12^{0} \mathrm{~F}\right)$ per decade (NOAA, 2007). Since the mid-1970s, however, the rate of increase in temperature rise has tripled. The IPPC's report (IPCC, 2007) warns that climate change could lead to impacts that are abrupt or irreversible.

The effects of climate change vary from region to region (Book, Niang, Nyong, et al.,(2007);Mimara, Nurse, Mclean et al.,(2007); Anisimov, Vaugh, Callaghan et al., (2007); Magrin, Garcia, and choque et al, (2007)). While wealthy, developed countries are mainly responsible for the historic buildup of climate changing gases, as well as high per capital emission (Moore and MacCracken 2009), leading global development organizations recognize that the poor in lower income countries are most vulnerable to climate change (Heltberg and Bonch-Osmolovskiy, 2008). The IPCC predicts growth of drought-affected areas, lower water availability for large numbers of people and that events such as heat waves, drought, and storms will lead to more deaths and disease, especially for those not in aposition to adapt (IPCC, 2007).

Agriculture contributes about $21-25 \%, 60 \%$ and $65-80 \%$ of the total antrhropogenic emissions of carbondioxide, $\left(\mathrm{CO}_{2}\right)$ methane $\left(\mathrm{CH}_{4}\right)$ and Nitrous oxide $\left(\mathrm{N}_{2} \mathrm{O}\right)$, respectively (Duxbary, Mosier, 1993; Isserman, 1992 and Watson, Meira, Filho, Sanhuezq, 1992). Agriculture is also thought to be responsible for over $95 \%$ of the ammonia, $50 \%$ of carbon monoxide and $35 \%$ of the nitrogen oxide released into the atmosphere as a result of human activity (Isserman, 1992). 
According to Food and Agricultural organization (FAO, 2006), the animal agriculture sector is responsible for approximately $18 \%$, or nearly one-fifth of human induced greenhouses (GHG) emissions. In nearly every step of meat, egg, and milk production, climate changing gasses are released into the atmosphere potentially disrupting weather, temperature and ecosystem health (FAO. 2006). Agriculturalists can play an important part in preventing and repairing damage to the environment. However, mitigating these serious problems requires an in depth knowledge of the contribution of this sector to climate change. It is therefore necessary to answer the following questions. What role does animal agriculture play in global warming and how can the effects caused by livestock to global warming be curtailed?

Specifically, the study sought to:

(i) review causes of climate change;

(ii) assess the contribution of farm animal production to climate change; and

(iii) determine mitigation strategies to curtail the effect of climate change caused by livestock production.

\section{Methodology}

The study is a desk research. Literature from various sources (journals, internet materials, books etc) were synthesized and utilized for the study.

\section{Results and Discussion}

\section{Causes of climate change}

Climate change can be caused by natural and/or human (anthropogenic) factors. One natural warming phenomenon is the greenhouse effect, while the most important human influence is the production of GHGs. Over 2,500 scientists around the world discussed together the effect in 1985 under IPCC and agreed that anthropogenic emissions of GHG play a major role in climate change (Naqui and Sejian, 2011). The greenhouse effect is a blanketing effect by which atmospheric GHGs keep the earth's surface warm. Clouds, aerosols, and parts of the earth's surface reflect about one third of the sun's light that reaches the earth (Le Treut, Somerville and Cubasch et al, 2007). Three important GHGs are $\mathrm{CO}_{2}$, $\mathrm{CH}_{4}$ and $\mathrm{N}_{2} \mathrm{O}$ (Steinfeld, Gerber, Wassenaar, Castel et al., 2006). In naturally occurring quantities, these gases are not harmful, their presence in the atmosphere helps to sustain life on the planet by trapping some heat near the earth's surface. Total GHG contributes a very small portion $(<1 \%)$ of the gases in the earth's atmosphere (Naqvi and Sejian 2011). But these gases play very important role in maintaining the atmospheric temperature suitable for human, plant and other species of ecosystem. (Naqvi and Sejian 2011). This natural warming phenomenon is known as greenhouse effect. 


\section{Anthropogenic influences}

Although some natural occurrences contribute to GHG emissions (IPCC, 2007c), the overwhelming consensus among the world's most reputable climate scientists is that human activities are responsible for most of this increase in temperature (IPCC, 2007a ). One of the most significant human contributors to GHG emission is farm animal production. Although transportation and the burning of fossil fuels have typically been regarded as the chief contributors to GHG emissions, FAO (2006) reports the substantial role of the farm animal production sector, identifying it as a major threat to the environment. According to United Nations (2006c) cattle rearing alone generates more global warming GHGs, as measured in $\mathrm{CO}_{2}$ equivalent, than transportation. Animal agriculture sector emits $18 \%$ or nearly onefifth of human-induced GHG emissions more than the transport sector (Steinfeld et al 2006).

About 56 billion land animals are reared and slaughtered globally for human consumption annually (FAO, 2008) and livestock inventories are expected to double by 2050, with most increases occurring in the developing world (Steinfeld et al., 2006). As the numbers of farm animals reared for meat, egg, and dairy production rise, so do their GHG emissions. The United State Department of Agriculture (USDA) has noted that GHG emissions from livestock are inherently tied to livestock population sizes because the livestock are either directly or indirectly the source for the emission (Koneswaran1 and Nierenberg, 2008)

Globally, according to the FAO 67.5 billion land animals were raised for human consumption in 2008 (FAO, 2010). Since industrialized systems support much larger numbers of animals per unit area than extensive systems (Pew Commission on Industrialized Farm Animal Production, 2008), a global shift towards industrial production could result in larger farm animal populations over all. Globally, industrialized systems now produce half of all pork and about two-thirds eggs and poultry meat (FAO, 2009). In China, India, and Brazil, for example, producers increasingly favour intensive, industrial production systems (FAO, 2007) over more welfare-friendly practices. Industrial livestock production has grown at twice the rate of more traditional mixed farming systems and at more than six times the rate of production based on grazing (Verge, DeKimpe, and Desjardin, 2007)

\section{Agricultural sources of GHGs}

\section{(a) Methane}

According to Knipmeyer et al. (1998) methane is one of the primary greenhouse gases found in the earth's atmosphere. It is the principal component of natural gas and often serves as an energy source in homes, cars, and power plants. Methane is produced by the decomposition of organic matter in the absence of oxygen. This process is known as anaerobic decomposition (Knipmeyer, et al. 1998). 
Over half of the world's anthropogenic methane emissions are produced by agricultural activities. The primary sources of agricultural methane include domesticated ruminant livestock, rice cultivation and the handling and processing of livestock manure. The greatest agricultural source of methane, however, is domesticated ruminant livestock, such as cattle, sheep and goats. Methane from this source is produced by bacteria in the animal's digestive system that break down fibrous food (EPA, 2006). The animal releases the methane gas into the atmosphere mainly through its mouth and nostrils.

Ruminants, such as cattle, sheep and goats usually have a stomach divided into four chambers (Solomon, Qin Manning et al 2007) and emit methane during digestion Environmental Protection Agency, 2006). An adult cow emits 80-110kg of methane annually (Environmental Protection Agency www.epa.gov.methane/rlep/fag.html). The calculated animal and management parameters, and related methane emissions from enteric fermentation in Sweden and Nigeria is shown in Table I

TABLE 1

Methane emissions from enteric fermentation in Sweden and Nigeria

\begin{tabular}{lll}
\hline Parameters & Sweden & Nigeria \\
\hline Animal weight (Kg) & 650 & 250 \\
Milk production (Kg year- ${ }^{-1}$ ) & 8400 & 240 \\
Digestibility feed (\%) & 73 & 56 \\
Feed intake (Kg. animal. Year- ${ }^{-1}$ ) & 6416 & 2546 \\
Methane conversion factor from enteric & 130 & 59 \\
fermentation (Kg.animal.year- ${ }^{-1}$ ) & & \\
\hline Source; FAO, (2010) & &
\end{tabular}

\section{(b) Carbon dioxide $\left(\mathrm{CO}_{2}\right)$}

Carbon dioxide is widely considered the most important induced GHG (Steinfeld, Gerber, Wassenaar, Castel et al, 2006). The release of $\mathrm{CO}_{2}$ into the atmosphere due to human activities, such as deforestation and scraping of the earth's surface by machinery during cultivation, has had the largest impact on the climate relative to all other factors over the last 250 years (Foster, Ramaswamy, Artaxo et al. 2007). In 2005 atmospheric carbon dioxide levels were $36 \%$, or about 100 parts per million (ppm) higher than 250 years before, rising to $379 \mathrm{ppm}$ (Foster, et al, 2007). Carbondioxide has the most significant anthropogenic warming impact in the atmosphere (Foster, et al.,2007) because of its sheer volume of its emissions and its persistence in the atmosphere. Carbon dioxide remains in the atmosphere for centuries and or millinnia (Moore, and MacCracken, 2009). Therefore $\mathrm{CO}_{2}$ emissions, including those produced by animal agriculture, may remain in the atmosphere in 2100 and beyond (Moore and MaCracke, 2009; Climate institute, 2007). The farm animal sector contributes approximately $9 \%$ of annual anthropogenic $\mathrm{CO}_{2}$ emissions the largest sources of $\mathrm{CO}_{2}$ from animal agriculture 
not coming from the animals themselves, but from the inputs and land-use changes necessary to maintain and feed them (FAO 2010)

Expanding farm animal production plays a major role in deforestation, turning wooded areas into grazing land and cropland for the production of feed (FAO, 2010). Animal agriculture related deforestation may emit 2.4 billion tonnes of $\mathrm{CO}_{2}$ into the atmosphere each year (FAO, 2006). Tropical forests act as carbon sinks, sequestering carbon and preventing its release into the atmosphere (Steinfeld et al, 2006). Thus, deforestation releases large amount of carbon, both from soil and vegetation. Animal agriculture's role in deforestation has been especially devastating in South America, where expansion of pasture and arable land at the expense of forests has been the most prevalent (Steinfeld et al, 2006 ). In 2005, cattle ranching was found to be one of the main causes of deforestation of 1.2 million hectares of forest in Central America while 18 million disappear, in large part because of clearing land for grazing cattle (FAO, 2005).

Like forests, soils can serve as carbon sinks and the estimated total amount of carbon stored in soils is 1,100-1,600 billion tonnes;-more than twice the carbon in vegetation or in the atmosphere (Steinfeld, 2006). Human activities primarily agriculture however, have significantly depleted the amount of carbon sequestered in the soil. Food and Agricultural Organisation estimates that animal agriculturerelated releases from cultivated soils worldwide may total 28 million tonnes of $\mathrm{CO}_{2}$ annually (FAO, 2006; Steinfeld, 2006). Conventional tillage practices (scraping the soil with machinery) both lower the organic carbon content of the soil and produce significant $\mathrm{CO}_{2}$ emissions (Wikipedia nd). Food and Agricultural Organization estimates that 18 million tonnes of $\mathrm{CO}_{2}$ are emitted annually from cultivating corn soybean and wheat on approximately 1.8 million $\mathrm{Km}^{2}$ of arable land to feed animals raised for meat, eggs, and milk (FAO, 2008). Animal agriculture can also cause desertification due to overgrazing and trampling of rangelands by farm animals (FAO, 2008). Desertification tends to reduce the productivity and amount of vegetative cover, thus allowing $\mathrm{CO}_{2}$ to escape.

\section{(c) Nitrous oxide $\left(\mathrm{N}_{2} \mathrm{O}\right)$}

The agriculture sector is one the primary sources of anthropogenic nitrous oxide. The bulk of United State $\mathrm{N}_{2} \mathrm{O}$ emissions stem from fertilizing agricultural soils for crop production. Fertilization of agricultural soils can be by way of application of large amounts of synthetic nitrogen fertilizers or farm animal (organic) manure. Manure and urine from farm animals, once deposited on the soil, emit $\mathrm{N}_{2} \mathrm{O}$. In the United States, a 10\% rise in $\mathrm{N}_{2} \mathrm{O}$ emissions between 1990 and 2005 could be traced, in part to changes in the poultry industry, including an overall increase in the domestic stock of birds used for meat and egg production (EPA, 2007)

Nitrous oxide is 310 times more potent than carbon dioxide in its ability to affect climate change; and moreover, results of a recent scientific study indicate that nitrous oxide is currently the leading ozone-depleting substance being emitted (Bracmort, 2010). Nitrous oxide familiar to some as "laughing gas," contributes to 
climate change and ozone depletion. Once released, $\mathrm{N}_{2} \mathrm{O}$ lingers in the atmosphere for decades (its atmospheric lifetime is approximately 114 years) and is 310 times more effective at trapping heat in the atmosphere over a 100-year time frame than carbon dioxide $\left(\mathrm{CO}_{2}\right)$. Nitrous oxide emission quantity estimates have remained fairly constant over the last few years, hovering around 325 million metric tons carbon dioxide equivalent $\left(\mathrm{CO}_{2}\right)$.

\section{Mitigation of greenhouse gasses}

Ideally, GHG mitigation strategies should consider all greenhouse gases, their specific formation processes, and their overrall net effect, since efforts to mitigate GHG emissions at one point in the production chain may actually raise emissions at a later point (FAO, 2010). Recent research has identified a wide range of mitigation options for reducing emissions from livestock sources (FAO, 2010)

\section{Methane}

a. Dietary measures. Quantity of methane produced is strongly influenced by the form, quality and composition of feed. Feeding strategies likely to lower methane emissions include:

(i) Altering and improving diet for higher animal productivity. Feeding increased levels of starch, feeding supplementary dietary fat, and reducing the proportion of fibre in the diet are examples of potential methane reduction strategies.

(ii) Forage selection and management. Increasing forage quality combined with the management of stocking rates and rotational grazing strategies have been demonstrated to reduce enteric methane emissions (Mirzaei-Aghsaghali and Maheri-Sis, 2011).

(iii) Use of feed additives. Additives can manipulate rumen microflora populations to induce stable and modified rumen fermentation with lower emissions. Some of the additives are not permitted in the European Union, because they are considered medicine. Research on additives is still ongoing. However, in recent years, there is growing interest in the use of plant secondary compounds (tannins and saponins) as a $\mathrm{CH}_{4}$ mitigation strategy because of their natural origin in opposition to chemical additives. Legumes containing condensed tannin (lotuses) are able to lower methane by $12-15 \%$ (Beauchemin et al., 2008; Rowlinson et al., 2008). Biological additives such as yeast cultures of Saccharomyces cerevisiae has also been suggested to reduce $\mathrm{CH}_{4}$ production by rumen microflora (McGinn et al., 2004).

\section{b. Herd management for increased animal productivity.}

Management systems designed for high milk output per cow will tend to result in lower emissions per unit of milk produced. In contrast, more extensive systems require more animals to produce a given quantity of milk-- resulting in higher methane output per litre. The opportunities to reduce methane emissions by 
increased animal productivity are larger in the extensive systems compared to the intensive systems with already high milk production levels per cow.

\section{Manure management and treatment.}

Changes to manure handling practices including use of anaerobic digesters can improve energy efficiency as well as reduce methane output. Helpful manuremanagement techniques include frequent and complete removal of manure from indoor storage, deep cooling of manure, and management of bedding and manure heaps to avoid anaerobic conditions (IPCC (2006).

\section{Carbon dioxide}

Mitigation options as presented by (Paustian,, Cole,. Sauerbeck, and Sampson, 1998) include:

(a) Increasing carbon storage. Opportunities to increase carbon storage within dairy farming systems include:

(i) agricultural intensification to reduce the land needed for production. This can decrease the rate of land-use change

(ii) restoring soil carbon by improving soil management techniques adopting conservation tillage, surface-residue management, and mulch farming; cultivating crops with deep-root systems; developing and cultivating plants with high lignin content, especially in residues and roots; eliminating summer fallow and incorporating legumes and other appropriate cover crops in rotation; applying animal manure and non-toxic anthropogenic biosoil; enhancing biological $\mathrm{N}$ fixation; and increasing crop biomass production (Follett et al., 2005)

(iii) improved grassland management; and

(iv) changing from highly intensive, short duration pastures to more permanent grasslands, as well as reduced tillage, can also increase carbon sequestration.

(b) Increasing energy efficiency along the food chain. Energy efficiency can be improved in milking parlors and milk processing plants.

(c) Digestion of manure to produce heat and electricity will also contribute to lower fossil fuel energy use and $\mathrm{CO}_{2}$ emissions.

(d) Renewable energy may have a large role to play on farms and in processing as well. Individual mitigation measures must however be evaluated with regard to emission reduction potential, environmental trade-offs within and outside the livestock system, technical feasibility and specific costs. FAO (2010) notes that it is important to underscore that the implementation of GHG mitigation measures requires not only technological development, but also economic incentives, and institutional frameworks that are adapted to the specific farm conditions and regions 


\section{Nitrous Oxide}

Options to reduce nitrous oxide emissions from dairy systems as outlined by Velthof'

van Beusichem and Oenema (1999) include:

(a) Dietary manipulation to increase efficiency. Avoiding excess Nitrogen in the diet and/or making dietary Nitrogen more absorbable reduces Nitrogen excretion.

(b) Manure management techniques. Methods such as anaerobic digestion indirectly reduce $\mathrm{N}_{2} \mathrm{O}$ emissions when slurry is applied to land by decreasing the available $\mathrm{N}$ content. Increasing manure storage time and covering manure storage structures, also help.

(c) Grazing management methods. Reduced stocking and minimized grazing periods-which reduce compaction through grazing--increase soil aeration and are likely to result in lower emissions.

(d) Housing system and management. Options for mitigating emissions include more frequent removal of manure from housing floors, and changing housing systems. Animal housing and manure stores of straw-based systems result in higher $\mathrm{N}_{2} \mathrm{O}$ emissions than anaerobic slurry-based systems.

\section{Mitigation approaches in Nigeria}

Approaches that best reduce emissions depend on local conditions and therefore vary from region to region. In Nigeria, emission of GHGs is generally low based on low per capita energy and other resources consumption in the country (Ministry of Environment (ME), 2003). However, as pointed out by ME (2003), GHGs emission is expected rise in future as a result of increased numbers of livestock and high population growth rate with corresponding increase in per capita energy and other resource consumption.

Nigeria is prone to carbon and methane emissions and ways to cap these emissions have been suggested (Stephen, 2011). To mitigate $\mathrm{CO}_{2}$ emissions State ministries of environment should encourage the planting and maintenance of a number of fast growing, carbon trapping trees on animal rearing concentration areas, and even on busiest streets across major cities within the state. Fast growing Malaysian trees such as Albizzia falcata and candlenut as well as the broad leaves of banana plants are good $\mathrm{CO}_{2}$ trapping plants (Stephen, 2011). To mitigate $\mathrm{CH}_{4}$ emissions government should support waste management in all the states in Nigeria to have a sequel structure to safe disposal of organic matter from cattle by herdsmen. The Federal Government may also be looking at building large regional modern landfills in the six geopolitical zones of the country first to kick start development in waste management across the country (Stephen, 2011). 
By distributing safety waste bags to these people they will be able to keep the cleared dung of their livestock in the bag, instead of disposing them starkly. When herdsmen go around, one of them will be directed to dispose dung of cattle in the safety waste bags given to them; even at their locations, after sweeping they will be advised to place the dung in waste bags and also they will be taught how to tie them when filled to capacity.

They are expected to dispose these bags which will be carried by garbage carter to landfills within the State. Education and Strict laws will also be made to ensure that they comply with this for small, medium and large scale livestock watchovers. Accessibility to extremely cheap and almost free disposal will ensure maximum cooperation with the government.

This will help save the amount of methane that will be released carelessly to the environment. Livestock waste managers will incinerate them in incinerators or manage them in other ways available, e.g. biogas; to minimize gas release. Safe landfills will also ensure the gases don't decompose externally and get released to the environment.

\section{Implication for extension}

Agricultural extension and advisory services, both public and private, thus have a major role to play in providing farmers with information, technologies, and education on how to cope with climate change and ways to contribute to GHG mitigation. Extension should educate farmers (urban and rural) on the necessity and the urgency to mitigate greenhouse gases. Therefore the above mitigation strategies should be disseminated effectively and efficiently to farmers. However, Farmers should be made to understand government motive of the exercise to plant trees around their environment which is to help absorb most of these emissions produced there. Northern states should be educated on the necessity to plant trees like xerophytes, which grow in deserts absorbing $\mathrm{CO}_{2}$ at night and saving it for next day's photosynthesis instead of relying on transpiration in those extremely hot areas.

\section{Conclusion}

There is a clear indication that livestock production is one of the major sources of GHG emission which lead to climate change. The effect of climate change can be halted by applying mitigation strategies depending on location. Efficacious plants peculiar to the Nigerian environment and conditions should be planted and maintained around cities and mostly in the rural areas where heavy concentration of agricultural activities are going on. It is also important for government to have a structure of safe disposal of waste from cattle. 


\section{References}

Anisimov O.A, Vaughan D.G, Callaghan TV. (2007). Polar regions (Arctic and Antarctic). In: Parry M.L, Canziani OF, Palutikof J.P, van der Linden P.J, and Hanson C.E (eds.), Climate change: impacts, adaptation, and vulnerability. Contribution of Working Group II to the Fourth Assessment Report of the Intergovernmental Panel on Climate Change (Cambridge, United Kingdom: Cambridge University Press, p. 655).

Available: $\quad$ http://www.ipcc.ch/pdf/assessment-report/ar4/wg1/ar4-wg1ts.pdf. Accessed October 4th 2011

Beauchemin, K.A., Kreuzer, M., Mara, F. O. and McAllister, T.A. (2008). Nutritional management for enteric methane abatement: A review. Aust. J. Exp. Agric., 48: 21-27.

Boko, M., Niang, I., and Nyong, A..( 2007). Africa. In: Parry M.L, Canziani OF, Palutikof J.P, van der Linden, P.J, and Hanson, C.E. (eds.), Climate change: impacts, adaptation, and vulnerability. Contribution of Working Group II to the Fourth Assessment Report of the Intergovernmental Panel on Climate Change (Cambridge, United Kingdom: Cambridge University Press, p. 435).

Bracmort, K. (2010). Nitrous oxide from agricultural sources: Potential role in greenhouse gas emission reduction and ozone recovery. Congressional Research Service report 7-75700 www.crs.gov R40874. Accessed $6^{\text {th }}$ Oct. 2011

Climate Institute. (2007). Climate Change. Accessed September 17, 2010. Available: http://www.climate.org/topics/climate-change/index.html.

Duxbury J.M., Mosier A.R. (1993). Status and issues concerning agricultural emissions of greenhouse gases. In: Kaiser H.M., and Drennen T.W. (Eds.), Agricultural Dimensions of Global Climate Change, St. Lucie Press, Delray Beach, F.L, , p. 229-258.

Environmental Protection Agency (EPA).( 2007). Ruminant livestock frequent questions. U.S. Accessed 24 October 2007. Available http;//www.epa.gov/methane/sorces.html

EPA (2006). Methane; sources and emissions in the U.S. Accessed $30^{\text {th }}$ June 2012. Available http;//www.epa.gov/methane/sorces.html

Food and agricultural organization (FAO) (2010) The Impact of animal agriculture on the environment and climate change in India: A Focus on methane. HSI Fact Sheet. Hamane Society International. 
FAO (2006). Livestock and Major threat to the environment: remedies urgently needed. FAO Rome Available:

http;//www.fao.org/newsroom/en/news/2006/10000448/index.html Accessed $6^{\text {th }}$ Oct. 2011.

Food and Agriculture Organization of the United Nations (FAO). (2009). The state of food and agriculture: livestock in the balance, p. 27. Accessed October 5, 2010. Available: http://www.fao.org/docrep/012/i0680e/i0680e.pdf..

FAO (Food and agricultural organization) (2007). Desertification. Accessed 23 October 2007. Available http://www.fao.org/desertification/default.asp?lang=en Accessed $6^{\text {th }}$ Oct. 2011

FAO (2005). Cattle ranching is encroaching on forests in Latin America. June 8. Accessed April 23, 2008. Available: www.fao.org/newsroom/en/news/2005/102924/index.html. Accessed $6^{\text {th }}$ Oct. 2011

FAO (2008) An HSUS Report: The Impact of animal agriculture on global warming and climate change. Humane Society of the United Nation. Accessed $6^{\text {th }}$ Oct. 2011.

Follett R.F, Shafer S.R, Jawson M.D, Franzluebbers A.J (2005). Research and implementation need to mitigate greenhouse gas emissions from agriculture in the USA. Soil Till Res 83(1):159-166.

Foster P, Ramaswamy, V. and Artaxo, P. (2007). Changes in atmospheric constituents and in radiative forcing. In: Solomon S, Qin D, Manning M. (eds). Climate change 2007: The physical science basis. Contribution of working group 1 to the Fourth Assessment Report of the Intergovernmental Panel on Climate Change (Cambridge, United Kingdom and New york, NY, USA; Cambridge University Press, p. 135-136 FAQ 2.1).

Heltberg, R and Bonch-Osmolovskiy, M (2011). Mapping vulnerability to climate change. The World Bank Sustainable Development Network, Social Development Unit.

Koneswaran, G. and Nierenberg D (2008). Global farm animal production and global warming: Impacting and mitigating climate change ${ }_{1}$ Humane Society of the United States, Washington, DC, USA; 2Worldwatch Institute, Washington, DC, USA

Intergovernmental Panel on Climate Change (IPCC) (2007b). Synthesis report; summary for policymakers. Accessed 24 March 2008. Available: http://www.ipcc.ch/pdf/assessment-report/ar4/syr/ar4-syr-spm.pdf.

IPCC (2007). Climate change: The physical science bases. Accessed 24 March 2008. Available: http;//www.ipcc.ch/ipccreports/ar4-wg1.htm. 
IPCC, (2006): 2006 National Greenhouse Gas Inventory Guidelines. Institute of Global Environmental Strategies (IGES), Kanagawa, Japan

Isserman K. (1992). Territorial, continental and global aspects of C, N, P and S emissions from agricultural ecosystems. In NATO Advanced Res. Workshop (ARW) on Interactions of C, N, P and S Biochemical cycles, Springer-Verlag, Heidelberg,.

Knipmeyer C.K, Garton B.L and Birkenholz R.J. (1998). Global climate change and environmental stewardship by ruminant livestock producers. United states Environmental Protection Agency and the National Council for Agricultural Education and the National FFA Foundation.

Le Treut H., Somerville R, Cubasch U,. (2007). Historical overview of climate change. In: Solomon S, Qin D, Manning M, et al (eds.), Climate change: the physical science basis. Contribution of Working Group I to the Fourth Assessment Report of the Intergovernmental Panel on Climate Change (Cambridge, United Kingdom and New York, NY, USA: Cambridge University Press, p. 104).

Magrin G, Gay Garcia C, and Cruz Choque D. (2007). Latin America. In: Parry M.L, Canziani O.F, Palutikof J.P, van der Linden P.J, and Hanson C.E (eds.), Climate change: impacts, adaptation, and vulnerability. Contribution of Working Group II to the Fourth Assessment Report of the Intergovernmental Panel on Climate Change (Cambridge, United Kingdom: Cambridge University Press, p. 583-584).

McGinn, S.M, S.M, Beauchmin, K.A., Coates, T. and Colombatto, D. (2004). Methane emissions from beef cattle; Effects of monensin, sunflower oil, enzymes, yeast and fumaric acid. J. Anim. Sci., 82:3346-3356

McMichael A.J, Powles J.W, Butler C.D, Uauy R. (2007). Food, livestock production, energy, climate change, and health. Accessed 11 November 2011. Available: http://www.ncbi.nlm.nih.gov/pubmed/17868818

Mimura N, Nurse L, McLean RF,. (2007). Small islands. In: Parry ML, Canziani OF, Palutikof J.P, van der Linden PJ, and Hanson CE (eds.), Climate change 2007: impacts, adaptation, and vulnerability. Contribution of Working Group II to the Fourth Assessment Report of the Intergovernmental Panel on Climate Change (Cambridge, United Kingdom: Cambridge University Press, p. 689).

Mirzaei-Aghsaghali, A and Maheri-Sis, N, (2011). Factors affecting mitigation of methane emission from ruminants I: Feeding strategies. Asian Journal of Animal and Veterinary Advances 6 (9); 888-908 
Ministry of Environment (2003). Nigeria's first national communication under the United Nations framework Convention on climate. The Ministry of Environment of the Federal Republic of Nigeria Abuja

Moore F.C, and MacCracken M.C. (2009). Lifetime-leveraging: an approach to achieving international agreement and effective climate protection using mitigation of short-lived greenhouse gases. International Journal of Climate Change Strategies and Management 1(1):42-62.

Moore F.C, and MacCracken M.C.(2009). Lifetime-leveraging: An approach to achieving international agreement and effective climate protection using mitigation of short-lived greenhouse gases. International Journal of Climate Change Strategies and Management 1(1)42-62.

Naqvi S.M.K. and Sejian V. (2011). Global climate change: role of livestock. Asian journal of Agricultural Sciences 3(1); 19-25.

National aeronautics and Space Adiminstration (NASA) (2006). 2005 warmest year in over a century Accessed 23 October 2007. Available: http://www.nasa.gov/vision/earth/environment/2005-warmes.html.National Oceanic and Atmospheric Administration (NOAA) (2007). Winter temperature near average, global December-February temperature warmest on record (Press release). Accessed 25 March 2008. Available: http://www.noaanews.noaa.gov/stories2007/s2819.htm

National Oceanic and Atmospheric Administration (NOAA) (2007). A Top Ten Warm Year for U.S. and Globe. United States Department of Commerce. Accessed 5/02/12. Available: http://www.noaanews.noaa.gov/stories2007/20071213 climateupdate.html

Paustian, K., Cole, C.V. Sauerbeck, D and Sampson, N. (1998). CO2 mitigation by agriculture: An overview. Climatic Change 40:135-162.

Pew Commission on Industrial Farm Animal Production (2008). Putting meat on the table; Industrial farm animal production in America, p. 23. Accessed October 5, 2010. Available;

Rowlinson, P., Steele, M. and Nefzaoui, A. (2008). Livestock and global climate change. Proceedings of the International Conferences in Hammamet, May 17-20, Cambridge University Press, 216-216.

Solomon S, Qin D, Manning M, (2007). Technical summary. In: Solomon S, Qin D, Manning $\mathrm{M}$, et al (eds.), Climate change: The physical science basis. Contribution of Working Group I to the Fourth Assessment Report of the Intergovernmental Panel on Climate Change (New York, NY: Cambridge University Press, p. 33 Table TS.2). Accessed on May 20, 2010. 
Steinfeld, H. Gerber P, Wassenaar T, Castel V, Rosales M, de Haan C. (2006). Livestock's Long Shadow: Environmental Issues and Options. Rome: food and Agricultural Organization of the United Nations

Stephen D. (2011). Capping Carbon and Methane Emissions in Nigeria. Sun newspaper. Saturday March, 05

Verge XPC, De Kimpe C, Desjardins R. L. (2007). Agricultural production, greenhouse gas emissions and mitigation potential. Agric. Forest Meteorol. 142: $255-269$.

Watson R.T., Meira Filho L.G., Sanhueza E., Janetos T. (1992). Sources and Sinks. In: Houghton J.T., Callander B.A., Varney S.K. (Eds.), Climate Change, Cambridge University Press, Cambridge, , p. 25-46. www.ncifap.org/bin/e/j/PCIFAPFin.pdf.

Wikipedia (nd.) The free encyclopedia http://en.wikipedia.org/wiki/Wikipedia 